\title{
Formation of secondary organic aerosol coating on black carbon particles near vehicular emissions
}

\author{
Alex K. Y. Lee ${ }^{1}$, Chia-Li Chen ${ }^{2}$, Jun Liu ${ }^{2}$, Derek J. Price ${ }^{2}$, Raghu Betha ${ }^{2}$, Lynn M. Russell ${ }^{2}$, Xiaolu Zhang ${ }^{3 \text {, a }}$, and \\ Christopher D. Cappa ${ }^{3}$ \\ ${ }^{1}$ Department of Civil and Environmental Engineering, National University of Singapore, Singapore \\ ${ }^{2}$ Scripps Institution of Oceanography, University of California, San Diego, USA \\ ${ }^{3}$ Department of Civil and Environmental Engineering, University of California, Davis, USA \\ a now at: Crocker Nuclear Laboratory, University of California, Davis, USA
}

Correspondence: Alex K. Y. Lee (ceelkya@ nus.edu.sg)

Received: 17 July 2017 - Discussion started: 31 July 2017

Revised: 4 November 2017 - Accepted: 16 November 2017 - Published: 20 December 2017

\begin{abstract}
Black carbon (BC) emitted from incomplete combustion can result in significant impacts on air quality and climate. Understanding the mixing state of ambient $\mathrm{BC}$ and the chemical characteristics of its associated coatings is particularly important to evaluate $\mathrm{BC}$ fate and environmental impacts. In this study, we investigate the formation of organic coatings on $\mathrm{BC}$ particles in an urban environment (Fontana, California) under hot and dry conditions using a soot-particle aerosol mass spectrometer (SP-AMS). The SPAMS was operated in a configuration that can exclusively detect refractory $\mathrm{BC}(\mathrm{rBC})$ particles and their coatings. Using the $-\log \left(\mathrm{NO}_{x} / \mathrm{NO}_{y}\right)$ ratio as a proxy for photochemical age of air masses, substantial formation of secondary organic aerosol (SOA) coatings on $\mathrm{rBC}$ particles was observed due to active photochemistry in the afternoon, whereas primary organic aerosol (POA) components were strongly associated with $\mathrm{rBC}$ from fresh vehicular emissions in the morning rush hours. There is also evidence that cooking-related organic aerosols were externally mixed from rBC. Positive matrix factorization and elemental analysis illustrate that most of the observed SOA coatings were freshly formed, providing an opportunity to examine SOA coating formation on $\mathrm{rBCs}$ near vehicular emissions. Approximately $7-20 \mathrm{wt} \%$ of secondary organic and inorganic species were estimated to be internally mixed with $\mathrm{rBC}$ on average, implying that $\mathrm{rBC}$ is unlikely the major condensation sink of SOA in this study. Comparison of our results to a co-located standard high-resolution time-offlight aerosol mass spectrometer (HR-ToF-AMS) measurement suggests that at least a portion of SOA materials con-
\end{abstract}

densed on rBC surfaces were chemically different from oxygenated organic aerosol (OOA) particles that were externally mixed with $\mathrm{rBC}$, although they could both be generated from local photochemistry.

\section{Introduction}

Black carbon (BC) emitted from incomplete combustion of fossil fuel and biomass has profound impacts on air quality and climate. $\mathrm{BC}$ is the dominant absorber of visible solar radiation in the atmosphere, introducing significant contributions to positive radiative forcing on both regional and global scales (Ramanathan and Carmichael, 2008; Bond et al., 2013). Organic coatings can be formed on BC through condensation and/or coagulation of co-emitted primary organic aerosol (POA) and secondary organic aerosol (SOA) produced via photochemical processing. The hydrophilic nature of SOA coating has been shown to modify hygroscopicity of ambient BC for cloud droplet activation (Kuwata et al., 2009; McMeeking et al., 2011; Laborde et al., 2013; Liu et al., 2013). Increasing coating thickness may enhance light absorption of BC due to a "lensing effect" depending on the degree of particle aging (Jacobson, 2001; Cappa et al., 2012; Peng et al., 2016; Liu et al., 2017) and alter BC morphology from highly fractal to compact structures and thus their aerodynamic properties (Moffet and Prather, 2009; Schnitzler et al., 2014; Guo et al., 2016; Peng et al., 2016). Understanding the mixing state of ambient $\mathrm{BC}$ and the chemical char- 
acteristics of its associated coatings is therefore particularly important to evaluate their fate and environmental impacts.

In typical urban environments, traffic emission is one of the major sources of BC particles. A complex mixture of gas-phase organic compounds with a wide range of volatilities and molecular structures are co-emitted with $\mathrm{BC}$ from vehicles, contributing prominently to the urban SOA burden (Gentner et al., 2017, and references therein). Although it is not straightforward to identify the role of individual SOA precursors, previous studies have shown that organic coating thickness of $\mathrm{BC}$ particles and their degree of oxygenation increased with photochemical age or oxidant levels in the atmosphere (Cappa et al., 2012; Liu et al., 2015; Wang et al., 2017). Of particular concern is the timescale that is required for sufficient SOA condensation to modify the physical, chemical, and optical properties of BC near emission sources. Peng et al. (2016) recently performed on-site chamber experiments to examine coating formation on sizeselected BC seeds using SOA precursors from particle-free ambient air, demonstrating that only a few hours of photochemical aging can lead to complete particle morphology modification and light absorption enhancement of $\mathrm{BC}$ in polluted urban regions. Moffet and Prather (2009) also provided field evidence that fresh BC can quickly evolve in terms of particle morphology in a photochemically active urban environment by developing coatings of secondary species over a timescale of several hours, highlighting the importance of local SOA chemistry in $\mathrm{BC}$ aging mechanisms.

While most previous studies focused on determining potential effects of SOA coatings on the BC properties, there is still a lack of laboratory and field investigations to examine effectiveness and selectivity of BC seed particles for condensation of SOA materials, especially in the presence of other existing seed particles. Recent field observations reported that SOA condensed on BC only accounted for 35 and $41 \%$ of total SOA mass near traffic emission sources and in a polluted offshore environment, respectively (Massoli et al., 2012, 2015). Metcalf et al. (2013) conducted a series of smog chamber experiments to investigate photooxidation of naphthalene and $\alpha$-pinene in the presence of both $\mathrm{BC}$ and ammonium sulfate seed particles with comparable surface area of each particle type. Although their observations indicated that the use of $\mathrm{BC}$ as a seed is not expected to alter the overall basic chemistry of SOA formation, whether the SOA condensed on $\mathrm{BC}$ particles is chemically different from that condensed on ammonium sulfate particles or formed through homogeneous nucleation remains unclear.

Real-time and mass-based chemical compositions of organic coatings on ambient BC particles were seldom reported until the recent development of an Aerodyne soot-particle aerosol mass spectrometer (SP-AMS; Cappa et al., 2012; Massoli et al., 2012, 2015; Onasch et al., 2012; Liu et al., 2015; Lee et al., 2016; Willis et al., 2016). In this study, we investigate formation of organic coatings on BC particles by deploying a SP-AMS in Fontana, California, which is located in the broader South Coast Air Basin and includes the greater Los Angeles area. The sampling site was located in an urban environment with strong influences of vehicular emissions. The SP-AMS was operated in a configuration that can exclusively detect refractory $\mathrm{BC}(\mathrm{rBC})$ and its coating materials. The term $\mathrm{rBC}$ is operationally defined (Onasch et al., 2012) and will be used throughout the rest of this paper. The repeated diurnal patterns of inorganic species, POA, and SOA that are internally mixed with $\mathrm{rBC}$ reported here provide a unique opportunity to investigate the chemical characteristics and formation of POA and SOA coatings on rBC particles near traffic emissions. A co-located Aerodyne high-resolution time-of-flight aerosol mass spectrometer (HR-ToF-AMS) was operated simultaneously to quantify the total amounts of non-refractory organic and inorganic species in $\mathrm{PM}_{1}$ (Chen et al., 2018). The results provide insights into the effectiveness of rBC particles as a condensation sink of fresh SOA near traffic emissions and the chemical characteristics of SOA coatings compared to SOA that was externally mixed with $\mathrm{rBC}$.

\section{Experiment}

\subsection{Sampling location and instrumentations}

The sampling site in Fontana, managed by the South Coast Air Quality Management District (SCAQM), was located behind the fire station at 14360 Arrow Highway $\left(34.100^{\circ} \mathrm{N}\right.$, $\left.117.490^{\circ} \mathrm{W}\right)$. Surrounded by the I- 15 freeway to the west $(4.3 \mathrm{~km}), \mathrm{I}-10$ freeway to the east $(3.9 \mathrm{~km})$, and the Auto Club Speedway to the south, the sampling site was strongly influenced by vehicular emissions, as well as the broader urban plume. Aerosol particle instruments housed in a sampling van with a custom isokinetic inlet were deployed. Air pulled through the inlet was dried using diffusion driers and subsequently distributed to different real-time particle instruments. This study focuses on the results from a SP-AMS (Aerodyne Research) that was configured to exclusively detect $\mathrm{rBC}$-containing particles and their coating materials (See Sect. 2.2 and 2.3 for the descriptions of the SP-AMS and the calibration approach, respectively). The details of other particle instruments, including a HR-ToF-AMS (Aerodyne Research), a single-particle soot photometer (SP2, Droplet Measurement Technologies), and a scanning electrical mobility spectrometer (SEMS, Brechtel), have been reported in Chen et al. (2018) and Betha et al. (2018). Two nitrogen oxide analyzers (model $42 \mathrm{i}$ and $42 \mathrm{i} \mathrm{NO}_{y}$, Thermo Fisher Scientific) were used to measure mixing ratios of $\mathrm{NO}_{x}$ and $\mathrm{NO}_{y}$ for determining photochemical age (PCA) of air masses. The heated molybdenum converter in the $42 \mathrm{i}$ nitrogen oxide analyzer was replaced by a UV-LED photolytic $\mathrm{NO}_{2}$ converter (Air Quality Design) for $\mathrm{NO}_{x}$ measurement. Hourly average ozone data was obtained from the co-located SCAQM air monitoring station. 


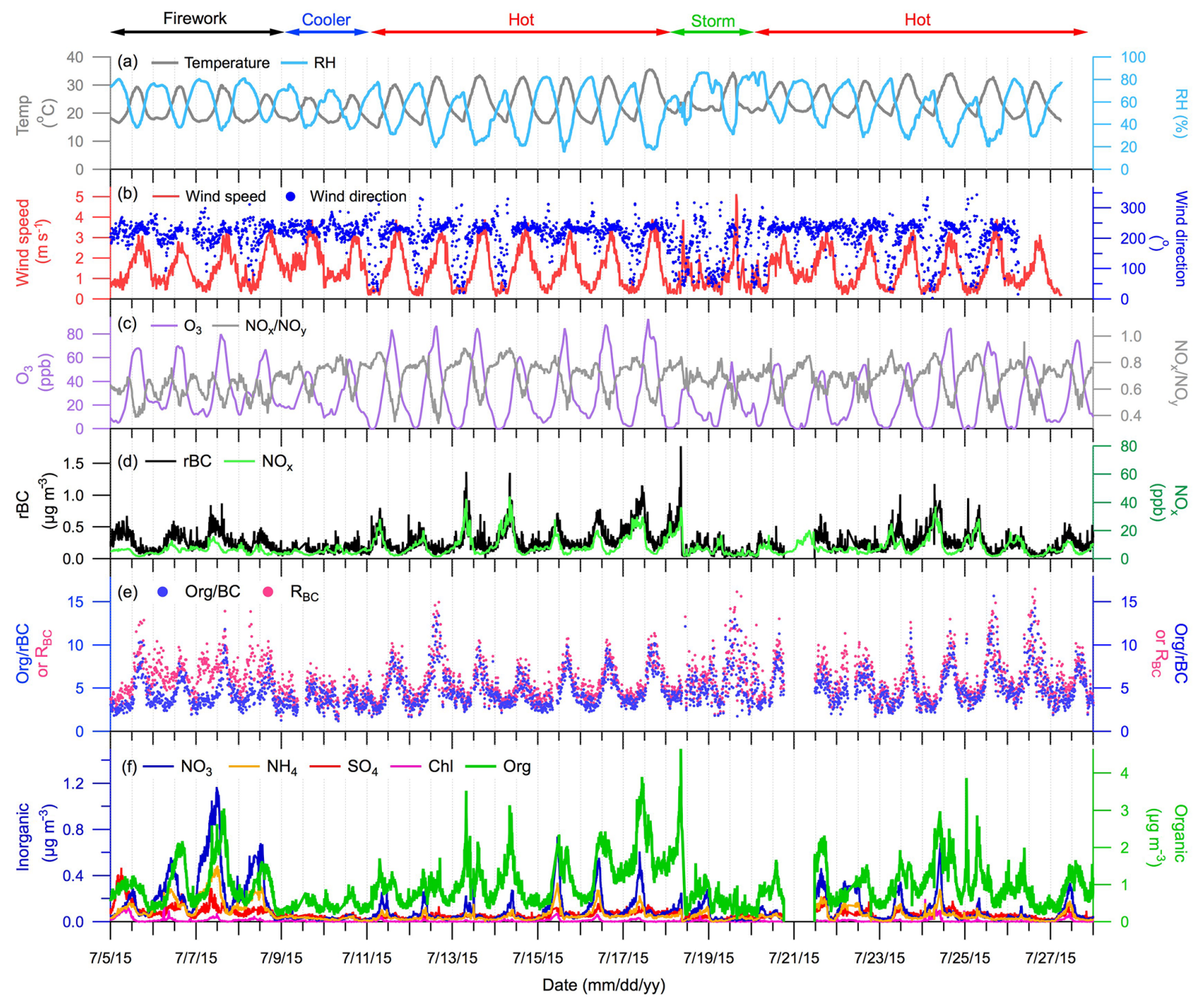

Figure 1. Time series of (a) temperature and $\mathrm{RH}$, (b) wind speed and direction, (c) ozone and $\mathrm{NO}_{x} / \mathrm{NO}_{y}$ ratio, (d) $\mathrm{rBC}_{\text {and }} \mathrm{NO}$, (e) $\mathrm{Org} / \mathrm{rBC}$ ratio and $R_{\mathrm{BC}}$, and (f) $\mathrm{NR}-\mathrm{PM}_{\mathrm{rBC}}\left(\mathrm{NO}_{3}\right.$ : nitrate; $\mathrm{NH}_{4}$ : ammonium; $\mathrm{SO}_{4}$ : sulfate; Chl: chloride; and Org: organic).

Measurements were performed from 5 to 28 July 2015 with ambient temperature varying from 14.9 to $35.9^{\circ} \mathrm{C}$. Companion studies have shown that aerosol compositions were strongly influenced by fireworks from 4 to 8 July 2015 (Chen et al., 2018; Betha et al., 2018). There were few clouds and little precipitation with the exception of a short storm with high rainfall and winds on 18-19 July (2-day precipitation $=3.6 \mathrm{~cm}$ and maximum wind speed $\left.=10 \mathrm{~ms}^{-1}\right)$. Sampling days with the maximum daily temperature above $30^{\circ} \mathrm{C}$ (11-17 and 20-28 July) and lower than $27^{\circ} \mathrm{C}(9-10$ July) were classified as "hot" and "cooler" days, respectively (Chen et al., 2018). The identified hot days were dry with the average hourly relative humidity $(\mathrm{RH})$ varying between 30 and $50 \%$ during the daytime. The Hybrid SingleParticle Lagrangian Integrated Trajectory (HYSPLIT) model with input from NOAA Air Resources Laboratory Archived Eta Data Assimilation System was used (https://www.arl. noaa.gov/HYSPLIT/) to evaluate whether particular upwind source regions affected the aerosol measured at the sampling site. Air mass back trajectories were consistently westerly from the coast within the entire sampling period except for the storm days (Chen et al., 2018). Classification of sampling periods based on meteorological conditions and pollutant characteristics is shown in Fig. 1.

\subsection{Soot-particle aerosol mass spectrometer (SP-AMS)}

The working principle of SP-AMS has been reported in detail previously (Onasch et al., 2012). In brief, rBC-containing particles are vaporized at $\sim 4000 \mathrm{~K}$ by a $1064 \mathrm{~nm}$ continuous wave intracavity infrared laser similar to that of the SP2 instrument (Onasch et al., 2012). The resulting vapor is ionized via $70 \mathrm{eV}$ electron impact and then detected by a HRToF-AMS operated in V-mode, which provides a mass resolving power of $\sim 2000$ at $m / z 28$ (DeCarlo et al., 2006; Canagaratna et al., 2007). Note that BC particles detected by the SP-AMS are operationally defined as $\mathrm{rBC}$. A resis- 
tively heated tungsten vaporizer was removed from our instrument so that only $\mathrm{rBC}$ and its coating materials were detected (Massoli et al., 2012, 2015; Lee et al., 2016; Willis et al., 2016). An efficient particle time-of-flight system (ePToF, multi-slit chopper with $50 \%$ aerosol throughput) was used for measuring aerosol size distributions. The SP-AMS was operated alternating between ensemble mode (i.e., $1 \mathrm{~min}$ average of bulk mass spectrum and PToF size distribution) and event trigger mode (i.e., single-particle mass spectrum with PToF size).

The SP-AMS was operated from 6 to 28 July 2015 and only the ensemble measurements are reported in this paper. The ensemble data were processed using the AMS data analysis software (Squirrel, version 1.56D for unit mass resolution data and Pika, version 1.15D for high-resolution data from http://cires1.colorado.edu/ jimenez-group/ToFAMSResources/ToFSoftware/) with the corrected air fragment column of the standard fragmentation table (Allan et al., 2004; DeCarlo et al., 2006). In particular, the average contribution of gas-phase $\mathrm{CO}_{2}$ to $\mathrm{CO}_{2}^{+}$organic fragments in the particle phase was determined (i.e., $\mathrm{CO}_{2}$-to$\mathrm{N}_{2}$ ratio) based on the measurements of particle-free ambient

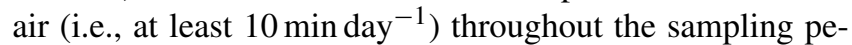
riod. Positive matrix factorization (PMF) was performed to investigate the potential sources and characteristics of $\mathrm{rBC}$ and organic aerosol components. Signals of $\mathrm{C}_{x}^{+}$fragments from $\mathrm{rBC}$ were included in the PMF analysis so that the mass fraction of $\mathrm{rBC}$ and organic components can be calculated for each PMF factor (Lee et al., 2015, 2016; Willis et al., 2016). The bilinear model was solved using the PMF2 algorithm in robust mode (Paatero and Tapper, 1994) and a final solution was selected using the PMF Evaluation Tool (PET) version 2.06 according to the method described previously (Ulbrich et al., 2009; Zhang et al., 2011). A four-factor solution, including two POA factors from traffic emissions and two SOA factors due to local photochemistry, was selected by examining the solutions for up to eight PMF factors (see Supplement). Elemental analysis (i.e., oxygen-to-carbon and hydrogen-to-carbon ratios, $\mathrm{O} / \mathrm{C}$ and $\mathrm{H} / \mathrm{C}$ ) was performed based on the improved ambient method (Canagaratna et al., 2015a).

\subsection{SP-AMS calibration}

A water suspension of REGAL Black (REGAL 400R Pigment Black, Cabot Corp., a calibration standard recommended by Onasch et al., 2012) was atomized using a constant output atomizer (TSI Inc., model 3076) for generating standard rBC particles. Dried $300 \mathrm{~nm}$ REGAL Black particles were used to determine mass-based ionization efficiency of $\mathrm{rBC}\left(\mathrm{mIE}_{\mathrm{rBC}}\right)$. Signals for REGAL Black particles were quantified by the sum of carbon ion clusters $\left(\mathrm{C}_{x}^{+}\right.$, i.e., $\mathrm{C}_{1}^{+}$$\mathrm{C}_{9}^{+}$) using high-resolution mass spectral data. The average $\mathrm{C}_{1}^{+}$-to- $\mathrm{C}_{3}^{+}$ratio of 0.478 obtained from REGAL Black calibration was used to correct the interference in $\mathrm{C}_{1}^{+}$from non- refractory organics in ambient aerosol. The product of material density and the Jayne shape factor (also defined as effective density, $\left.\rho_{\text {eff }}\right)$ of the dried $300 \mathrm{~nm}$ REGAL Black particles was $0.86 \pm 0.02 \mathrm{~g} \mathrm{~cm}^{-3}$, which can be derived from the ratio of the vacuum aerodynamic diameter $\left(d_{\mathrm{va}}\right)$ measured using the SP-AMS to the mobility diameter $\left(d_{\mathrm{m}}\right)$ selected by a differential mobility analyzer (DMA) as follows:

$\rho_{\text {eff }}=\rho_{\mathrm{m}} S=\left(d_{\mathrm{va}} / d_{\mathrm{m}}\right) \rho_{0}$,

where $\rho_{\mathrm{m}}$ and $S$ are the material density and Jayne shape factor, respectively, and $\rho_{0}$ is the unit density (DeCarlo et al., 2004). The average effective density of 0.86 and $d_{\mathrm{m}}$ was used to further calculate the mass of individual dried $300 \mathrm{~nm}$ REGAL Black particles (DeCarlo et al., 2004), which was approximately $12.2 \mathrm{fg}$. The average $\mathrm{mIE}_{\mathrm{rBC}}$ value was $255 \pm 50$ ions pg $^{-1}$ of REGAL Black particle based on three independent calibrations performed throughout the study.

Direct calibration of the ionization efficiency for nitrate $\left(\mathrm{IE}_{\mathrm{NO}_{3}}\right.$ ) is not possible without the tungsten vaporizer. Before removal of the tungsten vaporizer from the SP-AMS, dried $300 \mathrm{~nm}$ pure ammonium nitrate $\left(\mathrm{NH}_{4} \mathrm{NO}_{3}\right)$ and REGAL Black particles were generated for determining massbased ionization efficiency of nitrate $\left(\mathrm{mIE}_{\mathrm{NO}_{3}}\right)$ and $\mathrm{mIE}_{\mathrm{rBC}}$, respectively. Note that the $\mathrm{mIE}_{\mathrm{NO}_{3}}$ was determined without operating the laser vaporizer. The relative ionization of $\mathrm{rBC}\left(\mathrm{RIE}_{\mathrm{rBC}}=\mathrm{mIE} \mathrm{rBC}_{\mathrm{rB}} / \mathrm{mIE}_{\mathrm{NO}_{3}}\right)$ was 0.26 . Assuming that $\mathrm{RIE}_{\mathrm{rBC}}$ remains unchanged after removing the tungsten vaporizer, $\mathrm{mIE}_{\mathrm{NO}_{3}}$ and $\mathrm{IE}_{\mathrm{NO}_{3}}$ were calculated based on measured values of $\mathrm{mIE}_{\mathrm{rBC}}$. The calculated $\mathrm{IE}_{\mathrm{NO}_{3}}$ was then used with recommended RIE values (Jimenez et al. 2003; i.e., nitrate $=1.1$, sulfate $=1.2$, chloride $=1.3$, organics $=1.4$, and ammonium $=4$ ) to quantify non-refractory aerosol species associated with $\mathrm{rBC}$ (referred to as NR-PM $\mathrm{rBC}_{\mathrm{rBC}}$ ). Note that our previous studies have shown that this calibration approach likely yields the calculated $\mathrm{IE}_{\mathrm{NO}_{3}}$ values as a lower limit, leading to over-quantification of the NR-PM $\mathrm{M}_{\mathrm{rBC}}$ mass loadings in ambient aerosol (Willis et al., 2014; Lee et al., 2015).

The collection efficiency (CE) for rBC particles that is governed by the degree of overlap between particle and laser beams was determined using beam width probe (BWP) measurements described previously (Willis et al., 2014). Ambient $\mathrm{rBC}$-containing particles had an average beam width $(\sigma)=0.45 \pm 0.04 \mathrm{~mm}$ based on three sets of BWP measurements performed throughout the study. The measured particle beam width suggests a condition of incomplete beam overlap, arising from nonspherical $\mathrm{rBC}$ particles, and hence a CE of 0.6 was applied for absolute quantification of $\mathrm{rBC}$ and $\mathrm{NR}-\mathrm{PM}_{\mathrm{rBC}}$ (Willis et al., 2014). All BWP measurements were performed around the morning rush hours. Fresh rBC-containing particles from vehicular emissions in the morning had thinner coatings compared to those rBC-containing particles observed in the afternoon that were more photochemically aged (see discus- 
sion in Sect. 3). It has been demonstrated that $\mathrm{CE}$ for $\mathrm{rBC}$ particles increases (or rBC particle beam width decreases) with coating thickness (Willis et al., 2014). The applied CE may therefore be less relevant for the time with high ambient SOA loading (i.e., high NR-PM $\mathrm{rBC}_{\mathrm{rBC}} \mathrm{rBC}$ mass ratio, or $R_{\mathrm{BC}}$ ), leading to over-quantification of the SOA components in NR-PM $M_{\mathrm{rBC}}$ by at most $40 \%$ due to this uncertainty. Furthermore, a wider particle beam than the laser beam implies that some rBC-containing particles may undergo incomplete vaporization at the edges of the laser vaporizer, which would in turn bias the measurement towards the coatings rather than the rBC cores (see unpublished data from, http://cires1.colorado.edu/jimenez-group/ UsrMtgs/UsersMtg16/JDASPAMSfocusing.pdf). Since the $\mathrm{CE}$ of 0.6 was primarily determined for $\mathrm{rBC}$, this phenomenon may further increase the degree of over-

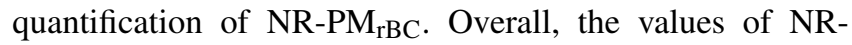
$\mathrm{PM}_{\mathrm{rBC}}$ reported in this work likely represent their upper limits.

\section{Results and discussion}

Figure 1 shows the time series of meteorological data (temperature, $\mathrm{RH}$, wind direction, and wind speed), mixing ratios of ozone and $\mathrm{NO}_{x}, \mathrm{NO}_{x} / \mathrm{NO}_{y}$ ratio, and chemical compositions of rBC-containing particles (i.e., rBC and NR-PM $\mathrm{rBC}_{\mathrm{rBC}}$ ) from 5 to 28 July 2015. The whole sampling period can be divided into four categories as previously reported (Chen et al., 2018; Betha et al., 2018). In brief, fireworks had strong impacts on aerosol compositions from 5 to 8 July, and significant enhancements of inorganic aerosol components were observed in rBC-containing particles (Fig. 1f). After the firework period, mass loadings of rBC-containing particles remained low from 9 to 10 July without clear diurnal patterns (indicated as cooler days in Fig. 1). A storm cleaned up the atmosphere from 18 to 19 July, leading to very low levels of all aerosol components within the two days. The SP-AMS was under maintenance from 20 July 18:00 to 21 July 12:00 PST (all times in Pacific standard time throughout). The weather was relatively hot and dry for the rest of sampling days (indicated as hot days in Fig. 1). Repeated diurnal patterns of the Org / $\mathrm{rBC}$ ratio (or $R_{\mathrm{BC}}$ ) with peak values in the afternoon were observed over the hot period (Fig. 1e), indicating a unique opportunity to examine POA and SOA formation on $\mathrm{rBC}$ near vehicular emissions via daytime chemistry. The observations during the hot period will be the focus of the following discussion.

\subsection{Chemical characteristics of $\mathrm{rBC}$ coating materials (NR-PM $\left.\mathbf{r B C}_{\mathbf{r}}\right)$}

Figure 2a shows the average diurnal cycles of rBC and NR$\mathrm{PM}_{\mathrm{rBC}}$ during the hot period. Mass loadings of rBC increased continuously in the morning rush hours and peaked at $\sim$ 08:00-09:00, and they were strongly correlated with the $\mathrm{NO}_{x}$ mixing ratio $(r=0.82)$, consistent with local traffic emissions as a major source (Fig. 1d). Boundary-layer breakup led to the decrease in $\mathrm{rBC}$ and $\mathrm{NO}_{x}$ concentrations (i.e., dilution as air from the residual layer mixed down to the surface). These diurnal patterns indicate that there were minimal influences of other combustion sources such as biomass burning and industrial emissions on the observed rBC concentrations. Nitrate and ammonium concentrations correlated well with each other $(r=0.97)$. Their mass loadings increased slowly over night and reached the maximum levels at $\sim 10: 00-11: 00$ in the morning (Fig. 2a). While $\mathrm{NO}_{2}$ reacts with ozone to generate $\mathrm{N}_{2} \mathrm{O}_{5}$ at night, $\mathrm{OH}$ radical oxidation of $\mathrm{NO}_{2}$ during the daytime produces nitric acid that can be neutralized by ammonia, forming particulate $\mathrm{NH}_{4} \mathrm{NO}_{3}$. A recent tunnel study has observed such $\mathrm{NH}_{4} \mathrm{NO}_{3}$ formation chemistry in aged traffic emissions (Tkacik et al., 2014). The decrease in particulate nitrate and ammonium (i.e., $\mathrm{NH}_{4} \mathrm{NO}_{3}$ ) concentrations could be the combined effects of boundary-layer breakup and evaporative loss at the increasing temperature during the day. Sulfate remained in low concentrations with a relatively modest pattern (see also Fig. 5d) potentially caused by the transport of regional pollution into the area during the day. Chloride was also associated with traffic (see also Fig. 5e) and was likely due to condensation of $\mathrm{HCl}$ vapor that was subsequently neutralized by ammonia (i.e., formation of $\mathrm{NH}_{4} \mathrm{Cl}$ ).

Organic aerosol (OA) was the dominant component of NR-PM $\mathrm{rBC}_{\mathrm{r}}$ during the hot period as illustrated in Fig. 2a. Mass loadings of organic coating increased with rBC concentrations in the morning rush hours. PMF results show that two primary emission factors, referred to as hydrocarbon-likeOA-rich (HOA-rich) and rBC-rich factors hereafter, were the major contributors to the total OA mass during the morning rush hours (Fig. 3e and $\mathrm{f}$ ). The mass concentration of the rBC-rich factor was slightly lower than the HOA-rich factor. Mass spectra of PMF factors indicate that $\mathrm{rBC}$ accounted for 14.2 and $44.4 \mathrm{wt} \%$ of the HOA-rich and $\mathrm{rBC}$-rich factors, respectively. The fragmentation pattern of $\mathrm{rBC}$ was similar to that previously reported in urban environments near traffic emissions and engine exhausts (Massoli et al., 2012; Lee et al., 2015; Enroth et al., 2016; Willis et al., 2016; Saarikoski et al., 2017). With the support of single-particle measurement, Willis et al. (2016) also separated traffic-related OA into HOA- and $\mathrm{rBC}$-rich factors in the roadside environment using a SP-AMS with the tungsten vaporizer removed and estimated that approximately $90 \%$ of rBC mass emitted from vehicles resided in $\mathrm{rBC}$-rich particles. By following the calculation procedure described in Willis et al. (2016), rBC-rich factor contributed about $82 \mathrm{wt} \%$ of the freshly emitted rBC from traffic. Note that $\mathrm{rBC}$-rich particles were composed of more oxygenated organic fragments compared to the HOArich factor (Fig. 3a and b), likely due to the presence of refractory ion fragments (i.e., $\mathrm{CO}^{+}$and $\mathrm{CO}_{2}^{+}$) that originated from oxygenated functionalities on the soot surface and in 


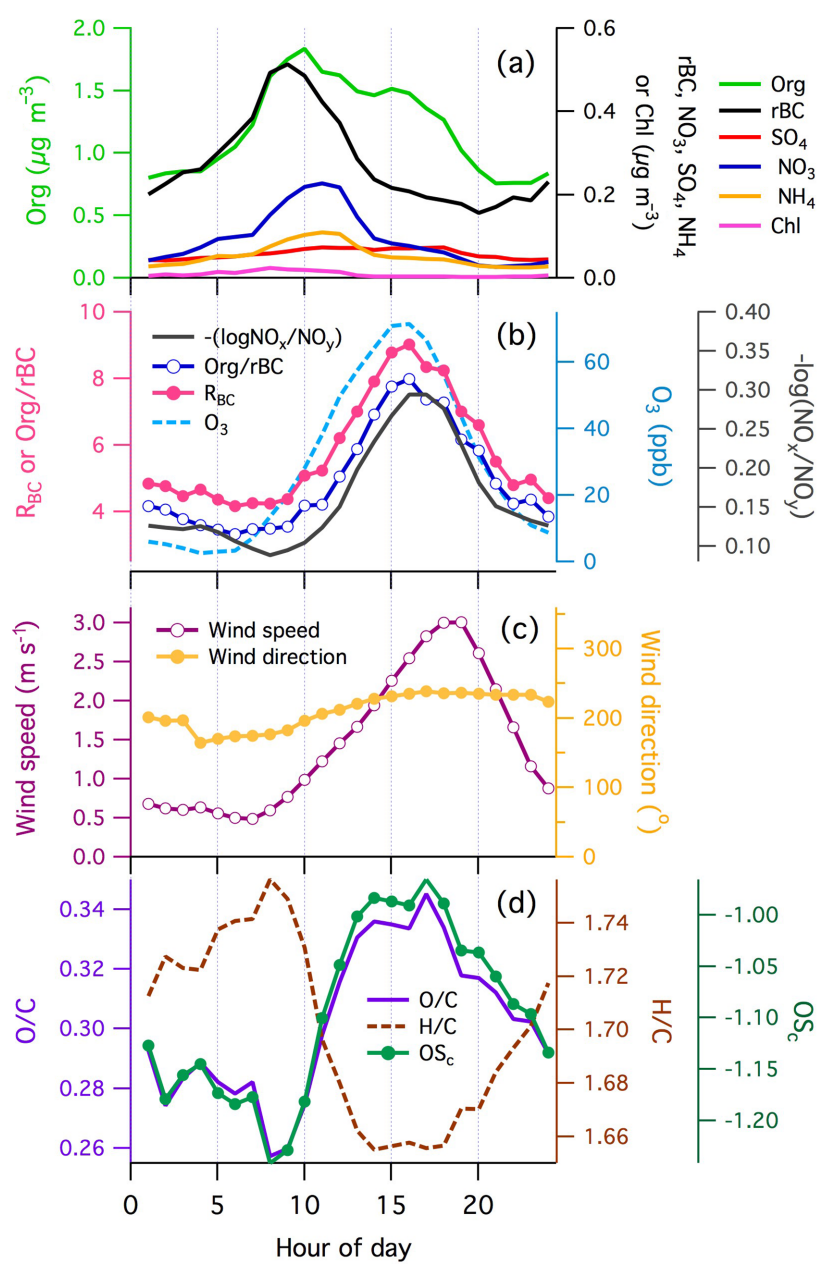

Figure 2. Diurnal cycles of (a) $\mathrm{rBC}$ and $\mathrm{NR}-\mathrm{PM}_{\mathrm{rBC}}$, (b) the Org / $\mathrm{rBC}$ ratio, $R_{\mathrm{BC}}$, ozone and $-\log \left(\mathrm{NO}_{x} / \mathrm{NO}_{y}\right)$, (c) wind speed and direction, and (d) $\mathrm{O} / \mathrm{C}, \mathrm{H} / \mathrm{C}$, and $\mathrm{OS}$ within the hot period (See Fig. S7 in the Supplement for the uncertainties of data).

the soot nanostructure (Corbin et al., 2014; Malmborg et al., 2017).

Using $-\log \left(\mathrm{NO}_{x} / \mathrm{NO}_{y}\right)$ as a proxy for PCA of air masses and the Org / rBC ratio (or $R_{\mathrm{BC}}$ ) as an indicator for SOA formation, production of fresh SOA coating materials on $\mathrm{rBC}$ particles was observed due to active photochemistry in the afternoon (Fig. 2b). The secondary nature of organic coatings observed in the afternoon peak was supported by the diurnal cycles of $\mathrm{O} / \mathrm{C}, \mathrm{H} / \mathrm{C}$, and average carbon oxidation state $\left(\mathrm{OS}_{\mathrm{c}} \approx 2 \mathrm{O} / \mathrm{C}-\mathrm{H} / \mathrm{C}\right.$; Kroll et al., 2011) of total OA (Fig. 2d). Higher values of $\mathrm{O} / \mathrm{C}$ and $\mathrm{OS}_{\mathrm{c}}$ were observed in the afternoon compared to in the morning rush hours, consistent with the expectation that the $\mathrm{O} / \mathrm{C}$ ratio of SOA is greater than POA. The PMF analysis identified two types of oxygenated OA (OOA), referred to as OOA-1 and OOA2 hereafter, both of which are likely SOA coatings. Mass spectra of both OOA factors were dominated by an oxygencontaining organic fragment at $m / z 43$ (i.e., $\mathrm{C}_{2} \mathrm{H}_{3} \mathrm{O}^{+}$; Fig. $3 \mathrm{c}$ and d), similar to those previously observed by Massoli et al. (2015). OOA-1 represented less oxygenated SOA components $(\mathrm{O} / \mathrm{C}=0.53)$ with $13.4 \mathrm{wt} \%$ of $\mathrm{rBC}$ content, and its concentration started increasing in the morning coincident with nitrate and ammonium (i.e., peaks at 10:00-11:00; Figs. $2 \mathrm{a}$ and $3 \mathrm{~g}$ ) and sustained at relatively constant levels until 15:00-16:00. This suggests a possibility that OOA-1 represented a fresher portion of SOA coating materials generated by photochemistry of anthropogenic gas-phase precursors from vehicular emissions. OOA-2 represented a more oxygenated fraction of SOA coating $(\mathrm{O} / \mathrm{C}=0.62)$ with the maximum mass loadings observed at $\sim 15: 00-16: 00$ and its diurnal pattern matched well with Org / $\mathrm{rBC}$ ratios (Figs. $2 \mathrm{~b}$ and $3 \mathrm{~h}$ ). The diurnal pattern of OOA-2 indicates the importance of local photochemistry for OOA-2 production in the afternoon but the contribution of regional transport to OOA2 cannot be completely ruled out. Given that $\mathrm{rBC}$ accounted for only $0.5 \mathrm{wt} \%$ of OOA-2 (i.e., much lower than other PMF factors), OOA-2 could represent SOA materials generated through local photochemistry and/or formed regionally under conditions with relatively low rBC particle concentrations.

\subsection{Chemical characteristics of $\mathrm{OA}$ as a function of $\boldsymbol{R}_{\mathrm{BC}}$}

Figure 4 a illustrates that $R_{\mathrm{BC}}$ increased continuously as a function of $-\log \left(\mathrm{NO}_{x} / \mathrm{NO}_{y}\right)$ within the hot period. Assuming that ambient daytime $\mathrm{OH}$ radical concentration was $\sim 4 \times 10^{6}$ molecules $\mathrm{cm}^{-3}$ (Takegawa et al., 2006; Slowik et al., 2011) and the major $\mathrm{NO}_{x}$ loss product was $\mathrm{HNO}_{3}$, the estimated PCA values (i.e., $\mathrm{PCA} \approx-\ln \left(\left[\mathrm{NO}_{x}\right] /\left[\mathrm{NO}_{y}\right]\right) / k_{\mathrm{rxn}}$ $[\mathrm{OH}])$ were about $5-7 \mathrm{~h}$ in the afternoon given that the rate constant between $\mathrm{OH}$ radicals and $\mathrm{NO}_{x}$ for $\mathrm{HNO}_{3}$ formation $\left(k_{\text {rxn }}\right)$ is equal to $7.9 \times 10^{-12} \mathrm{~cm}^{3}$ molecules ${ }^{-1} \mathrm{~s}^{-1}$ (Brown et al., 1999; Cappa et al., 2012). Such estimation further supports our hypothesis that OOA-1 and OOA-2 were fresh SOA produced in the local atmosphere. Furthermore, OA components became more oxygenated as the PCA and $R_{\mathrm{BC}}$ increased (i.e., solid circles with the colored scale of OS in Fig. 4a). Figure 4c illustrates that $\sim 85-90 \mathrm{wt} \%$ of total NR-PM $M_{\mathrm{rBC}}$ was organic regardless of the values of $R_{\mathrm{BC}}$. POA from traffic emissions (i.e., rBC- and HOA-rich factors) accounted for $\sim 50-70 \mathrm{wt} \%$ of total NR-PM $\mathrm{rBC}_{\mathrm{rC}}$ when $R_{\mathrm{BC}}$ was smaller than 4 , whereas the contributions of SOA components (i.e., OOA-1 and OOA-2 factors) increased with $R_{\mathrm{BC}}$, reaching a plateau at about $70-75 \%$ of total NR-PM $\mathrm{PBC}$ when $R_{\mathrm{BC}}$ was larger than 8 .

Figure $4 \mathrm{~b}$ shows that $R_{\mathrm{BC}}$ decreased continuously with higher rBC loadings, highlighting the fact that most of the rBC mass observed within the hot period was associated with POA materials. Based on the mass fraction of $\mathrm{rBC}$ signals in the mass spectra of each PMF factor, it can be estimated that over $80 \mathrm{wt} \%$ of rBC mass was associated with trafficrelated POA (i.e., about 60 and $20 \mathrm{wt} \%$ from rBC-rich and HOA-rich factors, respectively) when $R_{\mathrm{BC}}$ was smaller than 

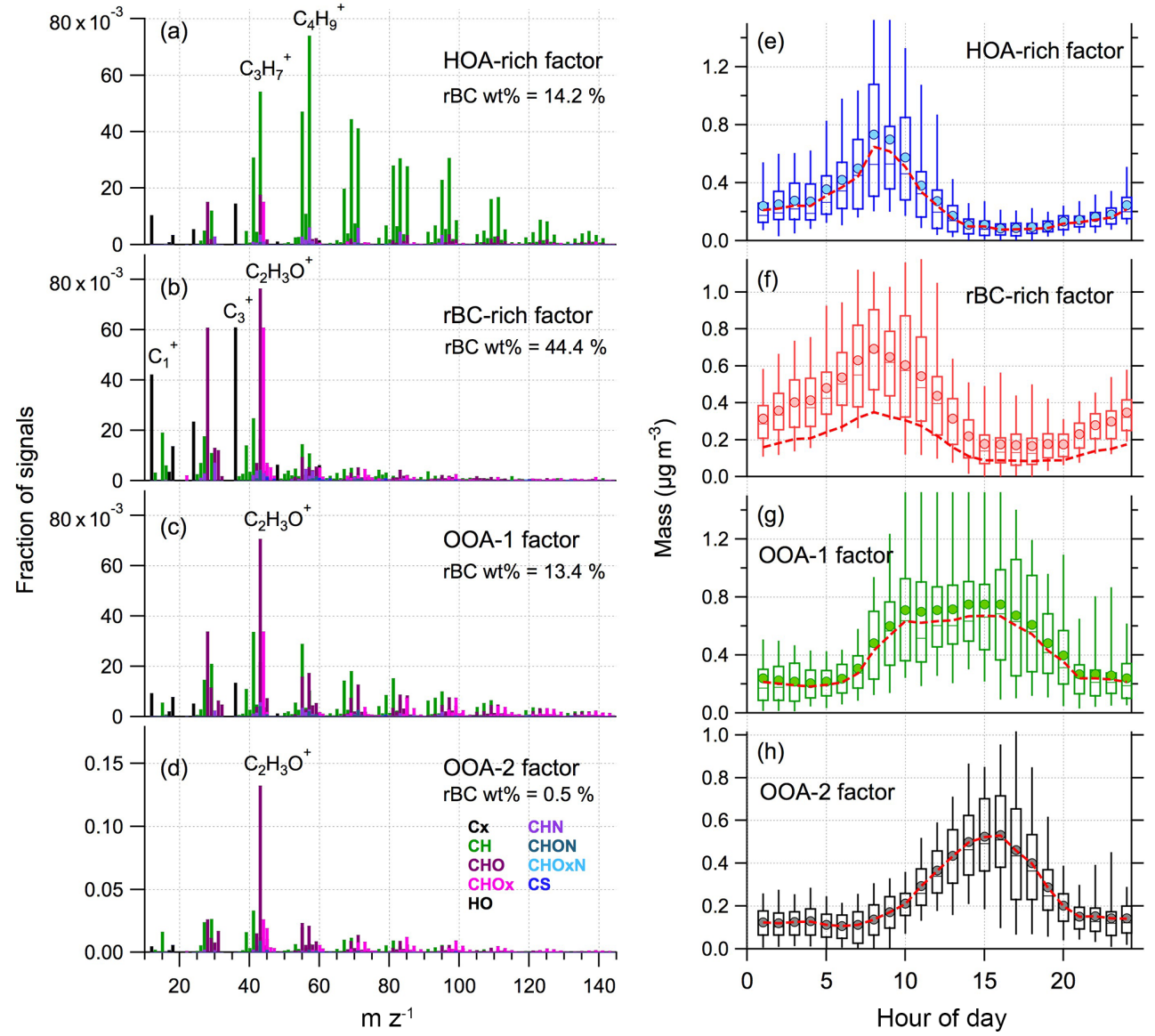

Figure 3. Mass spectra (a-d) and diurnal cycles (e-h) of PMF factors from SP-AMS data within the hot period. (Box plots: 5th, 25th, 50th, 75th, and 95th percentiles. Filled circles: mean values for organic $+\mathrm{C}_{x}^{+}$fragments. Red dashed lines: mean values for organic alone. RIEs of 0.26 and 1.4 were applied for $\mathrm{rBC}$ and organic fragments, respectively, for the diurnal patterns.).

4 (Fig. 4d). An increasing contribution of OOA factors to $\mathrm{rBC}$ mass was observed for particles with a thicker OA coating. The OOA-1 factor contributed up to $\sim 60 \mathrm{wt} \%$ of $\mathrm{rBC}$ mass when $R_{\mathrm{BC}}$ was larger than 10 , while the OOA-2 factor was only a minor contributor to $\mathrm{rBC}$ mass for the whole range of $R_{\mathrm{BC}}$ values. The small contribution of OOA-2 particles to the $\mathrm{rBC}$ burden occurred despite the substantial contribution of OOA-2 to the total NR-PM $\mathrm{rBC}_{\mathrm{rBC}}$ mass. This is because $\mathrm{rBC}$ accounted for only $0.5 \mathrm{wt} \%$ of the OOA-2 factor, implying that such OOA materials coexisted with small $\mathrm{rBC}$ inclusions. Willis et al. (2014) reported that the SP-AMS could accurately measure the mass fraction of $\mathrm{rBC}$, at least down to $0.05(5 \mathrm{wt} \%)$, in laboratory-generated organically coated REGAL Black particles. Vaporization efficiency of an individual particle with a tiny $\mathrm{rBC}$ core diameter (e.g., $<5 \mathrm{wt} \%$ ) and its uncertainties to mass quantification remain unclear (e.g., insufficient volatilization may lead to an underestimate of mass in the factor).

\subsection{Comparisons of NR-PM $\mathrm{rBC}_{\mathrm{r}}$ and NR-PM components}

To understand the mixing state of $\mathrm{OA}$ and $\mathrm{rBC}$ particles, the SP-AMS measurements (NR-PM $\mathrm{M}_{\mathrm{rBC}}$ ) were compared to the co-located HR-ToF-AMS measurements (NR-PM) as presented in Figs. 5 and 6. Mass loadings of secondary species in NR-PM $\mathrm{MBC}_{\mathrm{rBC}}$ were lower than their corresponding NR-PM components based on the $\mathrm{CE}$ and $\mathrm{IE}_{\mathrm{NO}_{3}}$ values used in this work, suggesting that significant fractions of secondary aerosol species were externally mixed with rBC. Specifically, diurnal cycles of nitrate, ammonium, and chloride were strongly correlated $(r>0.96)$ between the two measurements but only about $8-20 \mathrm{wt} \%$ (or NR-PM $\mathrm{rBC}_{\mathrm{rBC}} / \mathrm{NR}-\mathrm{PM}=0.08$ 0.2 ) of their masses were coated on $\mathrm{rBC}$. The fraction of sulfate that was internally mixed with $\mathrm{rBC}$ was small, on average $\left(\mathrm{NR}-\mathrm{PM}_{\mathrm{rBC}} / \mathrm{NR}-\mathrm{PM}=0.07\right)$. The relative abundance of HOA and OOA (i.e., comparing OA mass loadings in the morning and afternoon peaks in Fig. 5a) suggests that a larger fraction of OOA was externally mixed with $\mathrm{rBC}$ compared to HOA from traffic emissions, discussed further below. In gen- 

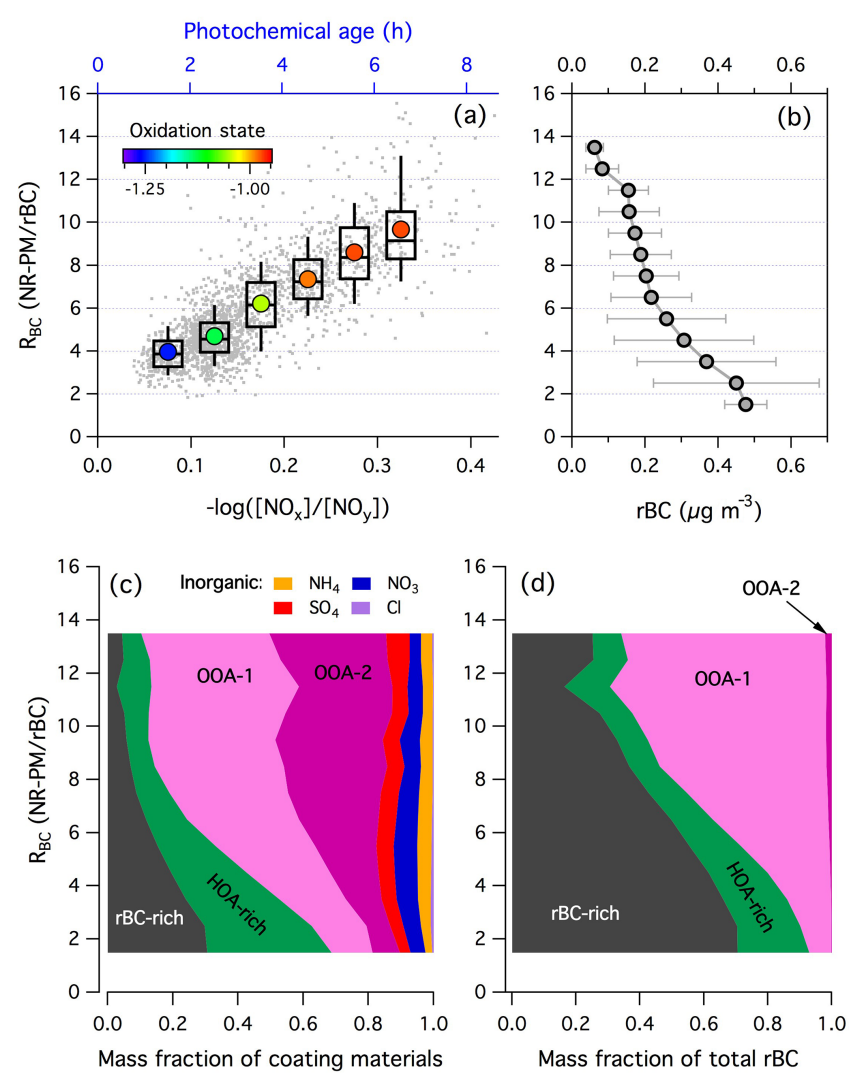

Figure 4. Coating thickness $\left(R_{\mathrm{BC}}\right)$ as a function of (a) photochemical age, (b) rBC mass loadings, (c) chemical compositions of coating, and (d) rBC mass fractions contributed by individual PMF factors within the hot period.

eral, OOA and sulfate tend to be concentrated in the accumulation mode, peaking between 400 and $600 \mathrm{~nm}$ in $d_{\mathrm{va}}$ (Zhang et al., 2011), and hence the argument above also explains the larger difference of OA and sulfate mass with $d_{\mathrm{va}}$ larger than $300 \mathrm{~nm}$ between the two measurements (Fig. 5i).

Chen et al. (2018) identified four PMF factors, namely HOA, cooking OA (COA), nitrate-related OOA (NOOA), and very oxygenated OA (VOOA), to describe the potential sources of OA measured with the HR-ToF-AMS (Fig. S6) in this field campaign. The HOA and COA factors are assumed to be primary and the NOOA and VOOA factors are assumed to be secondary in origin. First, HOA exhibited a strong peak in the morning rush hours, and its diurnal cycle and mass loading were very similar to the sum of rBC- and HOA-rich factors in terms of both shape and the absolute concentrations (Fig. 5f). HOA accounted for $9 \mathrm{wt} \%$ of total OA in NR-PM. Figure 6 further demonstrates that the average ratio of NR$\mathrm{PM}_{\mathrm{rBC}}$ / NR-PM for HOA components (i.e., ([HOA-rich] + [rBC-rich])/[HOA]) is about 1.32 , implying that HOA materials were largely internally mixed with $\mathrm{rBC}$ but their concentrations in $\mathrm{NR}-\mathrm{PM}_{\mathrm{rBC}}$ might be over-quantified by $32 \%$ on average based on our CE correction and ionization effi- ciency (IE) calibration approach. Note that the mass loadings of $\mathrm{rBC}$ contributing to the HOA-rich and $\mathrm{rBC}$-rich factors (estimated from the $\mathrm{C}_{n}^{+}$ions) were subtracted in the calculation of NR-PM $\mathrm{rBC}_{\mathrm{rBC}}$ / NR-PM. Nevertheless, the presence of refractory oxygenated organic fragments in the mass spectra of the rBC-rich factor could introduce positive biases to such estimation. The average ratio drops to about 1.05 if the three major oxygenated organic fragments, including $\mathrm{CO}^{+}, \mathrm{CO}_{2}^{+}$, and $\mathrm{C}_{2} \mathrm{H}_{3} \mathrm{O}^{+}$, are also excluded in the calculation. Using the same measurement approach and $R_{\mathrm{BC}}$-dependent $\mathrm{CE}$, Massoli et al. $(2012,2015)$ reported that 81 and $87 \%$ of HOA was associated with $\mathrm{rBC}$ particles near vehicular emissions and in a polluted offshore environment.

COA was another POA that contributed to $14 \mathrm{wt} \%$ of total OA in NR-PM. However, COA was not identified in the PMF analysis of SP-AMS data. The comparison suggests that $\mathrm{COA}$ was unlikely co-emitted with $\mathrm{rBC}$ from modern kitchens, and the mixing of $\mathrm{rBC}$ and $\mathrm{COA}$ through particle coalescence was insignificant near the sampling location. Similar observations have been reported in previous studies in downtown Toronto. Willis et al. (2016) could not identify $\mathrm{COA}$ by measuring $\mathrm{rBC}$-containing particles, whereas Lee et al. (2015) could separate a COA factor from other OA components by deploying a SP-AMS equipped with dual vaporizers (i.e., laser and tungsten vaporizers). Comparing the results obtained from two different operational modes (i.e., switching laser vaporizer on and off), Lee et al. (2015) provided indirect evidence that COA was largely externally mixed with $\mathrm{rBC}$ in the urban atmosphere.

SOA was the most abundant OA component. VOOA and NOOA accounted for 60 and $17 \mathrm{wt} \%$ of total OA in NRPM, respectively. Diurnal variations in NOOA were minimal, whereas VOOA mass concentrations increased continuously from $\sim$ 08:00 and peaked at $\sim$ 18:00 (Figs. 5g and S6). Although PMF analysis identified two SOA factors for both AMS measurements, the total SOA concentrations were calculated to provide overall comparisons of SOA mass loadings in NR-PM and NR-PM $\mathrm{PBC}_{\mathrm{rBC}}$ regardless of their sources. Specifically, $\mathrm{SOA}_{\mathrm{NR}-\mathrm{PM}}=\mathrm{NOOA}+\mathrm{VOOA}$ for HR-ToFAMS and $\mathrm{SOA}_{\mathrm{rBC}}=$ OOA-1 and OOA-2 for SP-AMS. The average $\mathrm{SOA}_{\mathrm{rBC}} / \mathrm{SOA}_{\mathrm{NR}-\mathrm{PM}}$ is equal to 0.2 , indicating that on average approximately $20 \mathrm{wt} \%$ of OOA components were internally mixed with $\mathrm{rBC}$ during the hot period (Fig. 6). It is worth noting that $\mathrm{SOA}_{\mathrm{rBC}}$ increased at a faster rate in the morning compared to $\mathrm{SOA}_{\mathrm{NR}-\mathrm{PM}}$, suggesting that $\mathrm{SOA}_{\mathrm{rBC}}$ and $\mathrm{SOA}_{\mathrm{NR}-\mathrm{PM}}$ could be produced or transported from different sources, at least to some extent. Furthermore, SOANR-PM mass concentrations started dropping substantially at $\sim 18: 00-19: 00$, which was about a $1-2 \mathrm{~h}$ delay compared to $\mathrm{SOA}_{\mathrm{rBC}}$ (Fig. 5g). This observable delay corresponded to the time of increasing sulfate levels in NR$\mathrm{PM}$, implying potential sources and formation pathways of VOOA (i.e., the major component of $\mathrm{SOA}_{\mathrm{NR}-\mathrm{PM}}$ within that period) that might be related to the regional transport of aged particles. This possible explanation is consistent with the ob- 

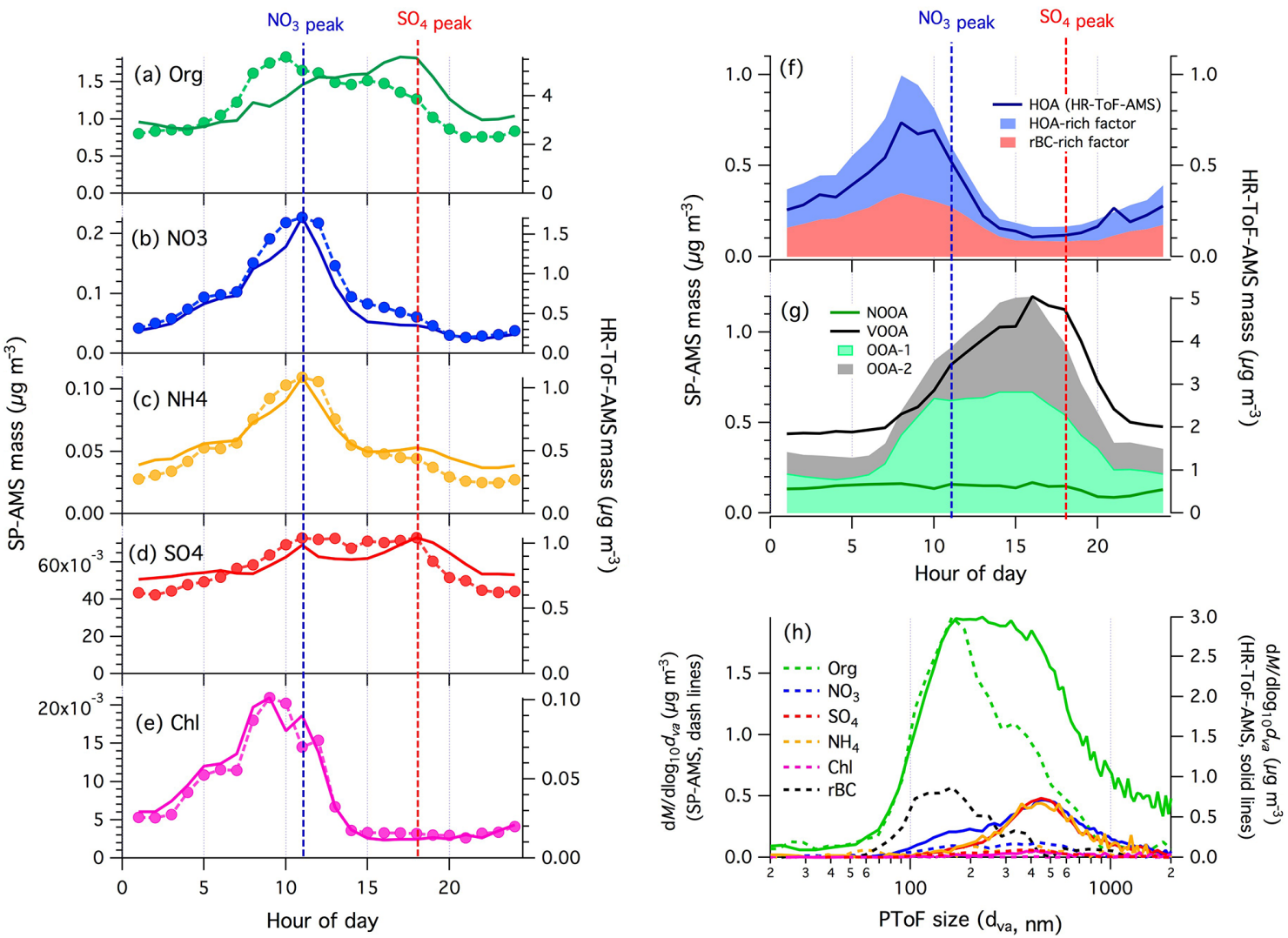

Figure 5. (a-e) Diurnal cycles of NR-PM and NR-PM $\mathrm{rBC}_{\mathrm{r}}$ measured with the HR-ToF-AMS (solid lines) and SP-AMS (dashed lines with circles), respectively. (f-g) Diurnal cycles of PMF factors from HR-ToF-AMS (solid lines) and SP-AMS (filled areas, organic components

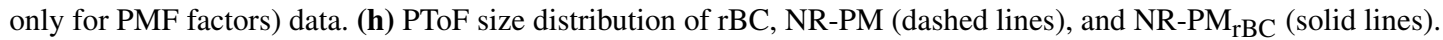

servation that VOOA represented more oxidized OOA materials (i.e., more aged) and that the strongest average wind speed was observed at around 18:00-19:00 (Fig. 2c). Singleparticle measurements using the light-scattering module of the HR-ToF-AMS also suggest internal mixing of sulfate and highly oxidized OOA materials in NR-PM (Chen et al., 2018). Nevertheless, VOOA could also be produced through local photochemistry as (1) it was unlikely that all the locally formed SOA materials were condensed on $\mathrm{rBC}$ particles exclusively during the day and (2) the HR-ToF-AMS should be able to detect OOA-1 and OOA-2 materials as well. The relative contributions of local photochemistry and regional transport to the observed VOOA mass could not be separated by the PMF analysis, possibly due to the chemical similarity of those SOA materials.

A key question remaining is whether the OOA materials identified by the SP-AMS and HR-ToF-AMS are the same in terms of AMS mass spectral characteristics. Figures 3 and S6 show that the mass spectra of OOA factors measured with the two instruments were clearly distinct from each other. Specifically, VOOA and NOOA were dominated by an organic fragment of $\mathrm{CO}_{2}^{+}$(i.e., a tracer of organic acids) and $\mathrm{C}_{2} \mathrm{H}_{3} \mathrm{O}^{+}$(followed by $\mathrm{CHO}^{+}$), respectively, whereas $\mathrm{C}_{2} \mathrm{H}_{3} \mathrm{O}^{+}$was the major fragment of OOA-1 and OOA-2. However, it is particularly important to point out that different aerosol vaporization schemes utilized in SP-AMS and HR-ToF-AMS make the direct comparison of organic mass spectra not straightforward. It has been demonstrated that thermal vaporization (operated at $600^{\circ} \mathrm{C}$ ) used in the HR-ToF-AMS produces significant decomposition and dehydration of oxidized organic compounds (Canagaratna et al., 2015a), but the laser vaporization used in SP-AMS can provide soft vaporization of organic coatings on $\mathrm{rBC}$ particles at a lower temperature, resulting in less molecular fragmentation (Canagaratna et al., 2015b). The OOA-1 and OOA-2 spectra notably have more peaks and with higher intensities at larger $m / z$ (>60 amu) compared to the NOOA and VOOA spectra. Also, the relative intensity of the peaks at $m / z 28$ and $29\left(\mathrm{CO}^{+}\right.$and $\mathrm{CHO}^{+}$, respectively) are substantially reduced in the OOA-1 and OOA-2 spectra compared to NOOA and VOOA. Both of these observations are consistent with reduced fragmentation from vaporization in the SP-AMS being a major reason for the differences.

The elemental ratios $(\mathrm{O} / \mathrm{C}$ and $\mathrm{H} / \mathrm{C})$ extracted from the SP-AMS and HR-ToF-AMS mass spectra of oxidized organic species have been shown to be different. Canagaratna 


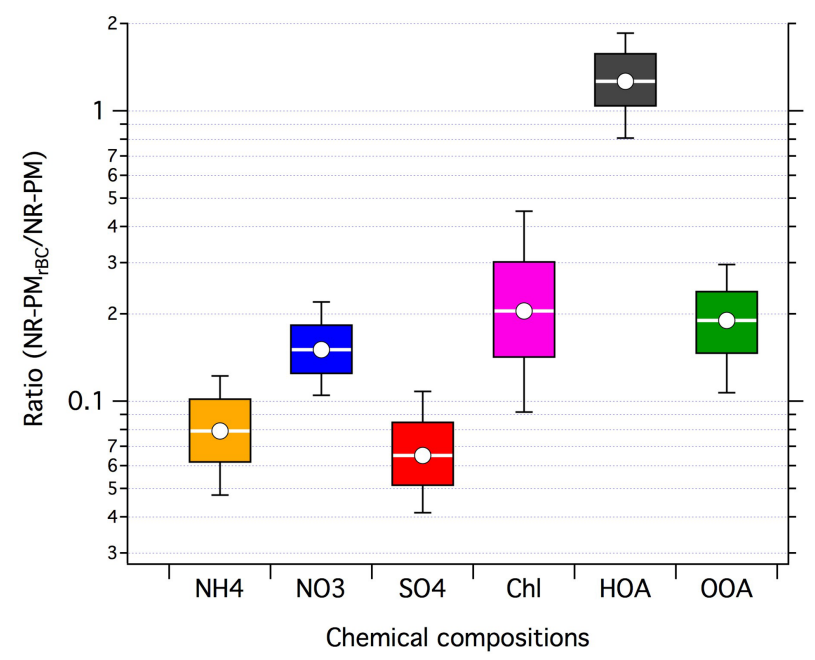

Figure 6. NR-PM $M_{\mathrm{rBC}}$-to-NR-PM ratios for individual aerosol components and PMF factors (box plots: 10th, 25th, 50th, 75th, and 90th percentiles; white circles: mean values; OOA $=([\mathrm{OOA}-1]$ $+[\mathrm{OOA}-2]) /([\mathrm{NOOA}]+[\mathrm{VOOA}])=\mathrm{SOA}_{\mathrm{rBC}} / \mathrm{SOA}_{\mathrm{NR}-\mathrm{PM}}$; and $\mathrm{HOA}=([\mathrm{HOA}-\mathrm{rich}]+[\mathrm{rBC}-\mathrm{rich}]) /[\mathrm{HOA}])$. Only organic components for PMF factors measured with the SP-AMS were used in this calculation. HOA loadings less than $0.15 \mu \mathrm{g} \mathrm{m}^{-3}$ from the HR-ToFAMS were removed for the calculation.

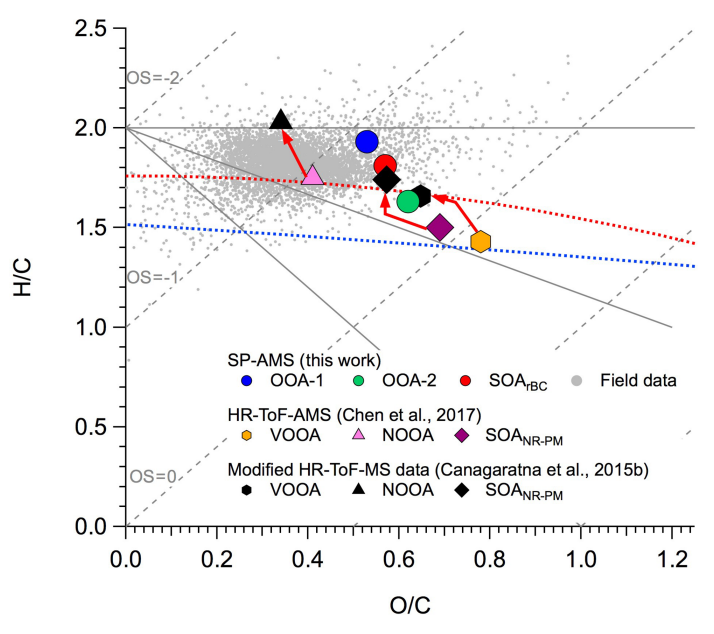

Figure 7. Van Krevelen diagram: red arrows indicate the changes in the elemental ratios of VOOA, NOOA factors, and SOANR-PM measured with the HR-ToF-AMS after applying the correction factors for more oxygenated organic species proposed by Canagaratna et al. (2015b).

et al. (2015b) reported that the SP-AMS O / C and H / C values differ from their corresponding HR-ToF-AMS values by factors of 0.83 and 1.16 , respectively, based on the laboratory analysis of chemical standards, including dicarboxylic acids, multifunctional acids, and alcohols. These conversion factors are applied to the $\mathrm{O} / \mathrm{C}$ and $\mathrm{H} / \mathrm{C}$ ratios of NOOA, VOOA, and $\mathrm{SOA}_{\mathrm{NR}-\mathrm{PM}}$ (i.e., mass-weighted values of NOOA and VOOA; Chen et al., 2018) in order to perform a more mean- ingful comparison to our SP-AMS measurements in the Van Krevelen diagram (Fig. 7). The elemental ratios of $\mathrm{SOA}_{\mathrm{rBC}}$ and $\mathrm{SOA}_{\mathrm{NR}-\mathrm{PM}}$ are comparable to each other, well within the measurement uncertainties. Similar observations are obtained between OOA-2 and VOOA. In contrast, the O / C and $\mathrm{H} / \mathrm{C}$ ratios of OOA-1 are rather different from the adjusted values of NOOA, VOOA, and SOANR-PM, suggesting some chemical difference between OOA-1 and those SOA materials. This is also consistent with the fact that OOA-1 mass concentrations increased faster than other OOA materials in the morning. More field and laboratory data are required to validate and improve the empirical relationships proposed by Canagaratna et al. (2015b) and to understand the extent to which the observed differences are a result of true chemical differences versus explainable by differences in molecular fragmentation due to the different vaporization schemes used in the instruments.

\section{Conclusions and atmospheric implications}

The repeated diurnal patterns of inorganic species, POA, and SOA reported here provide a unique opportunity to investigate the chemical characteristics and formation of the OA coating on $\mathrm{rBC}$ particles near traffic emissions. There is no doubt that HOA was significantly internally mixed with $\mathrm{rBC}$ as they were largely co-emitted by vehicles. The results of PMF illustrate that rBC- and HOA-rich factors accounted for about 60 and $20 \mathrm{wt} \%$ of rBC with a thin coating, respectively, and the rBC-rich factor contributed about $82 \mathrm{wt} \%$ of the freshly emitted rBC from traffic, similar to previous observations in the roadside environment (Willis et al., 2016). The COA factor is commonly observed in urban areas (Allan et al., 2010; Mohr et al., 2012) but its mixing with ambient $\mathrm{rBC}$ is seldom reported. The absence of a COA factor in $\mathrm{rBC}$-containing particles highlights the fact that emissions of $\mathrm{rBC}$ from modern kitchens and the mixing of $\mathrm{rBC}$ and COA through particle coalescence were negligible in this study. Previous measurements conducted in an urban area also pointed to the same conclusion (Lee et al., 2015; Willis et al., 2016).

Increases in coating thickness were primarily due to the substantial formation of fresh SOA through local photochemical processing on the timescale of a few hours. On average, about 7-20 wt \% of secondary aerosol species, including both inorganic and OOA species, were condensed on $\mathrm{rBC}$ particles, suggesting that $\mathrm{rBC}$ was unlikely the major sink for condensation of fresh SOA in this study. During the peak of SOA production, the average mass loadings of $\mathrm{rBC}$ and VOOA were about 0.2 and $4 \mu \mathrm{g} \mathrm{m}^{-3}$, respectively, which were a few factors to orders of magnitude lower than those generated in some recent aging experiments of soot particles (Metcalf et al., 2013; Li et al., 2017). Peng et al. (2016) recently showed that the timescale for producing sufficient fresh SOA to completely modify rBC properties strongly de- 
pends on pollution levels. Our observations may provide insight into the design of soot aging experiments for investigating the formation rate of fresh SOA coatings (e.g., growth rate of coating thickness) as well as their environmental impacts under a more atmospherically relevant condition.

Our measurement approach leads to a conclusion that at least a fraction of OOA condensed on $\mathrm{rBC}$ was chemically distinct from that externally mixed with $\mathrm{rBC}$, although uncertainties of organic fragmentation due to the application of the laser vaporizer still need to be fully established to quantify this difference. The reason for this unique observation remains unclear. One of the possibilities is that $\mathrm{SOA}_{\mathrm{rBC}}$ formed more locally on shorter timescales (e.g., photooxidation of anthropogenic volatile organic compounds near traffic emissions) could preferentially condense onto $\mathrm{rBC}$ particles in Aiken mode that can provide a larger overall surface area to the condensing gases compared to other existing background particles. The more oxidized OOA materials formed regionally on longer timescales (e.g., a fraction of VOOA that was largely externally mixed with $\mathrm{rBC}$ ) under conditions with relatively low concentrations of (or without) $\mathrm{rBC}$ particle could be advected to the sampling region during the day. Furthermore, atmospheric dilution of traffic emissions can modify the chemical compositions and concentrations of SOA precursors and seed particles so that the formation of secondary coatings on $\mathrm{rBC}$ might be less efficient and chemically different under diluted conditions (e.g., after boundary-layer breakup and mixing with air masses from the residual layer). This may partially explain the formation of VOOA in SOA NR-PM through local photochemistry. There may also be a mechanistic preference for material to condense onto certain surfaces because of their chemical nature (e.g., hydrophobic coating, such as HOA, and soot surface functionality) but future research efforts are required to explore this possibility further.

Data availability. The data used in this study are available from https://library.ucsd.edu/dc/collection/bb22212199.

\section{The Supplement related to this article is available online at https://doi.org/10.5194/acp-17-15055-2017- supplement.}

Competing interests. The authors declare that they have no conflict of interest.

Acknowledgements. Alex K. Y. Lee would like to acknowledge the support from the NUS start-up grant (R-302-000-173-133). Christopher D. Cappa and Lynn M. Russell were supported by the California Air Resources Board (agreement number: 13-330). The authors would also like to thank the Fontana Fire Department and the South Coast Air Quality Management District (SCAQMD) for
Fontana site logistics.

Edited by: Jacqui Hamilton

Reviewed by: two anonymous referees

\section{References}

Allan, J. D., Delia, A. E., Coe, H., Bower, K. N., Alfarra, M. R., Jimenez, J. L., Middlebrook, A. M., Drewnick, F., Onasch, T. B., Canagaratna, M. R., Jayne, J. T., and Worsnop, D. R.: A generalised method for the extraction of chemically resolved mass spectra from aerodyne aerosol mass spectrometer data, J. Aerosol Sci., 35, 909-922, https://doi.org/10.1016/j.jaerosci.2004.02.007, 2004.

Allan, J. D., Williams, P. I., Morgan, W. T., Martin, C. L., Flynn, M. J., Lee, J., Nemitz, E., Phillips, G. J., Gallagher, M. W., and Coe, H.: Contributions from transport, solid fuel burning and cooking to primary organic aerosols in two UK cities, Atmos. Chem. Phys., 10, 647-668, https://doi.org/10.5194/acp-10-6472010, 2010.

Betha, R., Russell, L. M., Chen, C.-L., Liu, J., Price, D. J., Sanchez, K. J., Chen, S., Lee A. K. Y., Collier, S. C., Zhang, Q., Zhang, X., and Cappa, C. D.: Larger submicron particles for emissions with residential burning in wintertime San Joaquin Valley (Fresno) than for vehicle combustion in summertime South Coast Air Basin (Fontana), J. Geophys. Res.-Atmos., accepted, 2018.

Bond, T. C., Doherty, S. J., Fahey, D. W., Forster, P. M., Berntsen, T., DeAngelo, B. J., Flanner, M. G., Ghan, S., Karcher, B., Koch, D., Kinne, S., Kondo, Y., Quinn, P. K., Sarofim, M. C., Schultz, M. G., Schulz, M., Venkataraman, C., Zhang, H., Zhang, S., Bellouin, N., Guttikunda, S. K., Hopke, P. K., Jacobson, M. Z., Kaiser, J. W., Klimont, Z., Lohmann, U., Schwarz, J. P., Shindell, D., Storelvmo, T., Warren, S. G., and Zender, C. S.: Bounding the role of black carbon in the climate system: A scientific assessment, J. Geophys. Res.-Atmos., 118, 5380-5552, https://doi.org/10.1002/jgrd.50171, 2013.

Brown, S. S., Talukdar, R. K., and Ravishankara, A. R.: Rate constants for the reaction $\mathrm{OH}+\mathrm{NO} 2+\mathrm{M}-\mathrm{HNO} 3+\mathrm{M}$ under atmospheric conditions, Chem. Phys. Lett., 299, 277-284, https://doi.org/10.1016/s0009-2614(98)01283-4, 1999.

Canagaratna, M. R., Jayne, J. T., Jimenez, J. L., Allan, J. D., Alfarra, M. R., Zhang, Q., Onasch, T. B., Drewnick, F., Coe, H., Middlebrook, A., Delia, A., Williams, L. R., Trimborn, A. M., Northway, M. J., DeCarlo, P. F., Kolb, C. E., Davidovits, P., and Worsnop, D. R.: Chemical and microphysical characterization of ambient aerosols with the aerodyne aerosol mass spectrometer, Mass Spectrom. Rev., 26, 185-222, https://doi.org/10.1002/mas.20115, 2007.

Canagaratna, M. R., Jimenez, J. L., Kroll, J. H., Chen, Q., Kessler, S. H., Massoli, P., Hildebrandt Ruiz, L., Fortner, E., Williams, L. R., Wilson, K. R., Surratt, J. D., Donahue, N. M., Jayne, J. T., and Worsnop, D. R.: Elemental ratio measurements of organic compounds using aerosol mass spectrometry: characterization, improved calibration, and implications, Atmos. Chem. Phys., 15, 253-272, https://doi.org/10.5194/acp-15-253-2015, 2015a.

Canagaratna, M. R., Massoli, P., Browne, E. C., Franklin, J. P., Wilson, K. R., Onasch, T. B., Kirchstetter, T. W., Fortner, E. C., Kolb, C. E., Jayne, J. T., Kroll, J. H., and Worsnop, D. R.: Chem- 
ical Compositions of Black Carbon Particle Cores and Coatings via Soot Particle Aerosol Mass Spectrometry with Photoionization and Electron Ionization, J. Phys. Chem. A, 119, 4589-4599, https://doi.org/10.1021/jp510711u, 2015b.

Cappa, C. D., Onasch, T. B., Massoli, P., Worsnop, D. R., Bates, T. S., Cross, E. S., Davidovits, P., Hakala, J., Hayden, K. L., Jobson, B. T., Kolesar, K. R., Lack, D. A., Lerner, B. M., Li, S. M., Mellon, D., Nuaaman, I., Olfert, J. S., Petaja, T., Quinn, P. K., Song, C., Subramanian, R., Williams, E. J., and Zaveri, R. A.: Radiative Absorption Enhancements Due to the Mixing State of Atmospheric Black Carbon, Science, 337, 1078-1081, https://doi.org/10.1126/science.1223447, 2012.

Chen, C.-L., Chen, S., Russell, L. M., Liu, J., Price, D. J., Betha, R., Sanchez, K. J., Lee A. K. Y., Collier, S. C., Zhang, Q., Kumar, A., Kleeman, M., Zhang, X., and Cappa, C. D.: Organic aerosol particle chemical properties associated with residential burning and fog in wintertime San Joaquin Valley (Fresno) and with vehicle and firework emissions in summertime South Coast Air Basin (Fontana), under review, 2018.

Corbin, J. C., Sierau, B., Gysel, M., Laborde, M., Keller, A., Kim, J., Petzold, A., Onasch, T. B., Lohmann, U., and Mensah, A. A.: Mass spectrometry of refractory black carbon particles from six sources: carbon-cluster and oxygenated ions, Atmos. Chem. Phys., 14, 2591-2603, https://doi.org/10.5194/acp14-2591-2014, 2014.

DeCarlo, P. F., Slowik, J. G., Worsnop, D. R., Davidovits, P., and Jimenez, J. L.: Particle morphology and density characterization by combined mobility and aerodynamic diameter measurements. Part 1: Theory, Aerosol Sci. Technol., 38, 1185-1205, https://doi.org/10.1080/027868290903907, 2004.

DeCarlo, P. F., Kimmel, J. R., Trimborn, A., Northway, M. J., Jayne, J. T., Aiken, A. C., Gonin, M., Fuhrer, K., Horvath, T., Docherty, K. S., Worsnop, D. R., and Jimenez, J. L.: Field-deployable, high-resolution, time-of-flight aerosol mass spectrometer, Anal. Chem., 78, 8281, https://doi.org/10.1021/ac061249n, 2006.

Enroth, J., Saarikoski, S., Niemi, J., Kousa, A., Ježek, I., Mocnik, G., Carbone, S., Kuuluvainen, H., Rönkkö, T., Hillamo, R., and Pirjola, L.: Chemical and physical characterization of traffic particles in four different highway environments in the Helsinki metropolitan area, Atmos. Chem. Phys., 16, 5497-5512, https://doi.org/10.5194/acp-16-5497-2016, 2016.

Gentner, D. R., Jathar, S. H., Gordon, T. D., Bahreini, R., Day, D. A., El Haddad, I., Hayes, P. L., Pieber, S. M., Platt, S. M., de Gouw, J., Goldstein, A. H., Harley, R. A., Jimenez, J. L., Prevot, A. S. H., and Robinson, A. L.: Review of Urban Secondary Organic Aerosol Formation from Gasoline and Diesel Motor Vehicle Emissions, Environ. Sci. Technol., 51, 10741093, https://doi.org/10.1021/acs.est.6b04509, 2017.

Guo, S., Hu, M., Lin, Y., Gomez-Hernandez, M., Zamora, M. L., Peng, J. F., Collins, D. R., and Zhang, R. Y.: OH-Initiated Oxidation of m-Xylene on Black Carbon Aging, Environ. Sci. Technol., 50, 8605-8612, https://doi.org/10.1021/acs.est.6b01272, 2016.

Jacobson, M. Z.: Strong radiative heating due to the mixing state of black carbon in atmospheric aerosols, Nature, 409, 695-697, https://doi.org/10.1038/35055518, 2001.

Jimenez, J. L., Jayne, J. T., Shi, Q., Kolb, C. E., Worsnop, D. R., Yourshaw, I., Seinfeld, J. H., Flagan, R. C., Zhang, X. F., Smith, K. A., Morris, J. W., and Davidovits, P.:
Ambient aerosol sampling using the Aerodyne Aerosol Mass Spectrometer, J. Geophys. Res.-Atmos., 108, 8425, https://doi.org/10.1029/2001jd001213, 2003.

Kroll, J. H., Donahue, N. M., Jimenez, J. L., Kessler, S. H., Canagaratna, M. R., Wilson, K. R., Altieri, K. E., Mazzoleni, L. R., Wozniak, A. S., Bluhm, H., Mysak, E. R., Smith, J. D., Kolb, C. E., and Worsnop, D. R.: Carbon oxidation state as a metric for describing the chemistry of atmospheric organic aerosol, Nat. Chem., 3, 133-139, https://doi.org/10.1038/nchem.948, 2011.

Kuwata, M., Kondo, Y., and Takegawa, N.: Critical condensed mass for activation of black carbon as cloud condensation nuclei in Tokyo, J. Geophys. Res.-Atmos., 114, D20202, https://doi.org/10.1029/2009jd012086, 2009.

Laborde, M., Crippa, M., Tritscher, T., Jurányi, Z., Decarlo, P. F., Temime-Roussel, B., Marchand, N., Eckhardt, S., Stohl, A., Baltensperger, U., Prévôt, A. S. H., Weingartner, E., and Gysel, M.: Black carbon physical properties and mixing state in the European megacity Paris, Atmos. Chem. Phys., 13, 5831-5856, https://doi.org/10.5194/acp-13-5831-2013, 2013.

Lee, A. K. Y., Willis, M. D., Healy, R. M., Onasch, T. B., and Abbatt, J. P. D.: Mixing state of carbonaceous aerosol in an urban environment: single particle characterization using the soot particle aerosol mass spectrometer (SP-AMS), Atmos. Chem. Phys., 15, 1823-1841, https://doi.org/10.5194/acp15-1823-2015, 2015.

Lee, A. K. Y., Willis, M. D., Healy, R. M., Wang, J. M., Jeong, C.-H., Wenger, J. C., Evans, G. J., and Abbatt, J. P. D.: Singleparticle characterization of biomass burning organic aerosol (BBOA): evidence for non-uniform mixing of high molecular weight organics and potassium, Atmos. Chem. Phys., 16, 55615572, https://doi.org/10.5194/acp-16-5561-2016, 2016.

Li, K. W., Chen, L. H., Han, K., Lv, B. A., Bao, K. J., Wu, X. C., Gao, X., and Cen, K. F.: Smog chamber study on aging of combustion soot in isoprene/SO2/NOx system: Changes of mass, size, effective density, morphology and mixing state, Atmos. Res., 184, 139-148, https://doi.org/10.1016/j.atmosres.2016.10.011, 2017.

Liu, D., Allan, J., Whitehead, J., Young, D., Flynn, M., Coe, H., McFiggans, G., Fleming, Z. L., and Bandy, B.: Ambient black carbon particle hygroscopic properties controlled by mixing state and composition, Atmos. Chem. Phys., 13, 2015-2029, https://doi.org/10.5194/acp-13-2015-2013, 2013.

Liu, D. T., Whitehead, J., Alfarra, M. R., Reyes-Villegas, E., Spracklen, D. V., Reddington, C. L., Kong, S. F., Williams, P. I., Ting, Y. C., Haslett, S., Taylor, J. W., Flynn, M. J., Morgan, W. T., McFiggans, G., Coe, H., and Allan, J. D.: Black-carbon absorption enhancement in the atmosphere determined by particle mixing state, Nat. Geosci., 10, 184-188, https://doi.org/10.1038/ngeo2901, 2017.

Liu, S., Aiken, A. C., Gorkowski, K., Dubey, M. K., Cappa, C. D., Williams, L. R., Herndon, S. C., Massoli, P., Fortner, E. C., Chhabra, P. S., Brooks, W. A., Onasch, T. B., Jayne, J. T., Worsnop, D. R., China, S., Sharma, N., Mazzoleni, C., Xu, L., Ng, N. L., Liu, D., Allan, J. D., Lee, J. D., Fleming, Z. L., Mohr, C., Zotter, P., Szidat, S., and Prevot, A. S. H.: Enhanced light absorption by mixed source black and brown carbon particles in UK winter, Nat. Commun., 6, 184-188, https://doi.org/10.1038/ncomms9435, 2015. 
Malmborg, V. B., Eriksson, A. C., Shen, M., Nilsson, P., Gallo, Y., Waldheim, B., Martinsson, J., Andersson, O., and Pagels, J.: Evolution of In-Cylinder Diesel Engine Soot and Emission Characteristics Investigated with Online Aerosol Mass Spectrometry, Environ. Sci. Technol., 51, 1876-1885, https://doi.org/10.1021/acs.est.6b03391, 2017.

Massoli, P., Fortner, E. C., Canagaratna, M. R., Williams, L. R., Zhang, Q., Sun, Y., Schwab, J. J., Trimborn, A., Onasch, T. B., Demerjian, K. L., Kolb, C. E., Worsnop, D. R., and Jayne, J. T.: Pollution Gradients and Chemical Characterization of Particulate Matter from Vehicular Traffic near Major Roadways: Results from the 2009 Queens College Air Quality Study in NYC, Aerosol Sci. Technol., 46, 1201-1218, https://doi.org/10.1080/02786826.2012.701784, 2012.

Massoli, P., Onasch, T. B., Cappa, C. D., Nuamaan, I., Hakala, J., Hayden, K., Li, S. M., Sueper, D. T., Bates, T. S., Quinn, P. K., Jayne, J. T., and Worsnop, D. R.: Characterization of black carbon-containing particles from soot particle aerosol mass spectrometer measurements on the R/V Atlantis during CalNex 2010, J. Geophys. Res.-Atmos., 120, 2575-2593, https://doi.org/10.1002/2014jd022834, 2015.

McMeeking, G. R., Good, N., Petters, M. D., McFiggans, G., and Coe, H.: Influences on the fraction of hydrophobic and hydrophilic black carbon in the atmosphere, Atmos. Chem. Phys., 11, 5099-5112, https://doi.org/10.5194/acp-115099-2011, 2011.

Metcalf, A. R., Loza, C. L., Coggon, M. M., Craven, J. S., Jonsson, H. H., Flagan, R. C., and Seinfeld, J. H.: Secondary Organic Aerosol Coating Formation and Evaporation: Chamber Studies Using Black Carbon Seed Aerosol and the SingleParticle Soot Photometer, Aerosol Sci. Technol., 47, 326-347, https://doi.org/10.1080/02786826.2012.750712, 2013.

Moffet, R. C. and Prather, K. A.: In-situ measurements of the mixing state and optical properties of soot with implications for radiative forcing estimates, P. Natl. Acad. Sci. USA, 106, 1187211877, https://doi.org/10.1073/pnas.0900040106, 2009.

Mohr, C., DeCarlo, P. F., Heringa, M. F., Chirico, R., Slowik, J. G., Richter, R., Reche, C., Alastuey, A., Querol, X., Seco, R., Peñuelas, J., Jiménez, J. L., Crippa, M., Zimmermann, R., Baltensperger, U., and Prévôt, A. S. H.: Identification and quantification of organic aerosol from cooking and other sources in Barcelona using aerosol mass spectrometer data, Atmos. Chem. Phys., 12, 1649-1665, https://doi.org/10.5194/acp-121649-2012, 2012.

Onasch, T. B., Trimborn, A., Fortner, E. C., Jayne, J. T., Kok, G. L., Williams, L. R., Davidovits, P., and Worsnop, D. R.: Soot Particle Aerosol Mass Spectrometer: Development, Validation, and Initial Application, Aerosol Sci. Technol., 46, 804-817, https://doi.org/10.1080/02786826.2012.663948, 2012.

Paatero, P., and Tapper, U.: Positive matrix factorization a nonnegative factor model with optimal utilization of error-estimates of data values, Environmetrics, 5, 111-126, https://doi.org/10.1002/env.3170050203, 1994.

Peng, J. F., Hu, M., Guo, S., Du, Z. F., Zheng, J., Shang, D. J., Zamora, M. L., Zeng, L. M., Shao, M., Wu, Y. S., Wang, Y., Glen, C. R., Collins, D. R., Molina, M. J., and Zhang, R. Y.: Markedly enhanced absorption and direct radiative forcing of black carbon under polluted urban environments, P. Natl. Acad. Sci. USA, 113, 4266-4271, https://doi.org/10.1073/pnas.1602310113, 2016.
Ramanathan, V. and Carmichael, G.: Global and regional climate changes due to black carbon, Nat. Geosci., 1, 221-227, https://doi.org/10.1038/ngeo156, 2008.

Saarikoski, S., Timonen, H., Carbone, S., Kuuluvainen, H., Niemi, J. V., Kousa, A., Ronkko, T., Worsnop, D., Hillamo, R., and Pirjola, L.: Investigating the chemical species in submicron particles emitted by city buses, Aerosol Sci. Technol., 51, 317-329, https://doi.org/10.1080/02786826.2016.1261992, 2017.

Schnitzler, E. G., Dutt, A., Charbonneau, A. M., Olfert, J. S., and Jager, W.: Soot Aggregate Restructuring Due to Coatings of Secondary Organic Aerosol Derived from Aromatic Precursors, Environ. Sci. Technol., 48, 14309-14316, https://doi.org/10.1021/es503699b, 2014.

Slowik, J. G., Brook, J., Chang, R. Y.-W., Evans, G. J., Hayden, K., Jeong, C.-H., Li, S.-M., Liggio, J., Liu, P. S. K., McGuire, M., Mihele, C., Sjostedt, S., Vlasenko, A., and Abbatt, J. P. D.: Photochemical processing of organic aerosol at nearby continental sites: contrast between urban plumes and regional aerosol, Atmos. Chem. Phys., 11, 2991-3006, https://doi.org/10.5194/acp11-2991-2011, 2011.

Takegawa, N., Miyakawa, T., Kondo, Y., Blake, D. R., Kanaya, Y., Koike, M., Fukuda, M., Komazaki, Y., Miyazaki, Y., Shimono, A., and Takeuchi, T.: Evolution of submicron organic aerosol in polluted air exported from Tokyo, Geophys. Res. Lett., 33, L15814, https://doi.org/10.1029/2006g1025815, 2006.

Tkacik, D. S., Lambe, A. T., Jathar, S., Li, X., Presto, A. A., Zhao, Y. L., Blake, D., Meinardi, S., Jayne, J. T., Croteau, P. L., and Robinson, A. L.: Secondary Organic Aerosol Formation from in-Use Motor Vehicle Emissions Using a Potential Aerosol Mass Reactor, Environ. Sci. Technol., 48, 11235-11242, https://doi.org/10.1021/es502239v, 2014.

Ulbrich, I. M., Canagaratna, M. R., Zhang, Q., Worsnop, D. R., and Jimenez, J. L.: Interpretation of organic components from Positive Matrix Factorization of aerosol mass spectrometric data, Atmos. Chem. Phys., 9, 2891-2918, https://doi.org/10.5194/acp-92891-2009, 2009.

Wang, Q. Y., Huang, R. J., Zhao, Z. Z., Cao, J. J., Ni, H. Y., Tie, X. X., Zhu, C. S., Shen, Z. X., Wang, M., Dai, W. T., Han, Y. M., Zhang, N. N., and Prevot, A. S. H.: Effects of photochemical oxidation on the mixing state and light absorption of black carbon in the urban atmosphere of China, Environ. Res. Lett., 12, 044012, https://doi.org/10.1088/1748-9326/aa64ea, 2017.

Willis, M. D., Lee, A. K. Y., Onasch, T. B., Fortner, E. C., Williams, L. R., Lambe, A. T., Worsnop, D. R., and Abbatt, J. P. D.: Collection efficiency of the soot-particle aerosol mass spectrometer (SP-AMS) for internally mixed particulate black carbon, Atmos. Meas. Tech., 7, 4507-4516, https://doi.org/10.5194/amt-7-45072014, 2014.

Willis, M. D., Healy, R. M., Riemer, N., West, M., Wang, J. M., Jeong, C.-H., Wenger, J. C., Evans, G. J., Abbatt, J. P. D., and Lee, A. K. Y.: Quantification of black carbon mixing state from traffic: implications for aerosol optical properties, Atmos. Chem. Phys., 16, 4693-4706, https://doi.org/10.5194/acp16-4693-2016, 2016.

Zhang, Q., Jimenez, J. L., Canagaratna, M. R., Ulbrich, I. M., Ng, N. L., Worsnop, D. R., and Sun, Y. L.: Understanding atmospheric organic aerosols via factor analysis of aerosol mass spectrometry: a review, Anal. Bioanal. Chem., 401, 3045-3067, https://doi.org/10.1007/s00216-011-5355-y, 2011. 